\title{
SCREENING AND CHARACTERIZATION OF L-GLUTAMINASE PRODUCED BY BACTERIA ISOLATED FROM SANGIHE TALAUD SEA
}

\section{Penapisan dan Karakterisasi L-Glutaminase yang Diproduksi oleh Bakteri dari Perairan Sangihe Talaud}

\author{
Tanti Yulianti ${ }^{3)}$, Ekowati Chasanah ${ }^{1)^{*}}$, and Usman Sumo Friend Tambunan ${ }^{2)}$ \\ ${ }^{1}$ Research and Development Center for Marine and Fisheries Product Processing and Biotechnology \\ 2 Department of Chemistry, Faculty of Mathematics and Science, Universitas Indonesia \\ ${ }^{3}$ National Agency of Drug and Food Control \\ "Corresponding author: ekowatichasanah@gmail.com. KS. Tubun Petamburan VI Jakarta Pusat 10260
}

\begin{abstract}
L-glutaminase (L-glutamine amidohydrolase, EC 3.5.1.2) is a very important enzyme due to its role as flavor enhancer and antileukemic agent. Salt-tolerant L-glutaminase produced by marine bacteria is favorable in food industries. This study describes the screening of Lglutaminase producing marine bacteria from Sangihe-Talaud Sea, North Sulawesi, Indonesia. Screening of L-glutaminase was performed using a liquid medium and identification of selected isolate was performed using molecular-based 16S rDNA. Results showed that there were 7 isolates produced positive results of L-glutaminase, and one of them (II.1 isolate) produced the highest activity, i.e $147.99 \mathrm{U} / \mathrm{L}$, equivalent to the specific activity of $62.32 \mathrm{U} / \mathrm{mg}$. The isolate then selected for further study. Bacterial identification based on 16S rRNA sequencing has revealed that the isolate was $96 \%$ similar to Pseudomonas aeruginosa strain CG-T8. Characterization of extracellular L-glutaminase from the II.1 isolate showed that the enzyme worked optimally at temperature of $37-45^{\circ} \mathrm{C}$ and $\mathrm{pH} 7$. The enzyme was stable when $\mathrm{NaCl}$ solution was added up to $8 \%$ and began to decrease on addition of $\mathrm{NaCl}$ solution of $16 \%$ and $20 \%$ with relative activity of $79 \%$ and $74 \%$, respectively. The effect of metal ions, e. $\mathrm{Mn}^{2+}, \mathrm{Mg}^{2+}$, and $\mathrm{Co}^{2+}$ in the form of chloride salt, were able to increase enzyme activity, whereas the addition of other metal ions $\left(\mathrm{Zn}^{2+}, \mathrm{Fe}^{3+}\right.$, and $\mathrm{Ca}^{2+}$ ) decreased the activity. The molecular weights of L-glutaminase was estimated around $42 \mathrm{kDa}$ and $145 \mathrm{kDa}$.
\end{abstract}

Keywords: L-glutaminase, marine bacteria, 16S rRNA, screening, characterization

\begin{abstract}
ABSTRAK
L-glutaminase (L-glutamine amidohydrolase, EC 3.5.1.2) merupakan enzim yang sangat penting karena perannya sebagai penghasil flavor dan anti leukimia. L-glutaminase yang tahan garam yang diproduksi oleh bakteri laut sangat diharapkan oleh industri pangan. Penelitian ini bertujuan untuk melakukan penapisan bakteri laut penghasil enzim dari perairan Sangihe-Talaud, Sulawesi Utara, Indonesia. Penapisan dilakukan dengan menggunakan medium cair, dan identifikasi bakteri penghasil enzim dilakukan secara molekuler menggunakan 16S rDNA. Hasil penelitian memperlihatkan bahwa dari 7 isolat yang positif L-glutaminase, 1 isolat (isolat II.1) menghasilkan aktivitas enzim tertinggi yaitu 147,99 U/L, setara dengan aktifitas spesifik 62,32 $\mathrm{U} / \mathrm{mg}$. Isolat ini selanjutnya dipelajari lebih lanjut. Berdasarkan identifikasi molekuler, isolat ini memiliki kemiripan 96\% dengan Pseudomonas aeruginosa strain CG-T8. Hasil karakterisasi enzim menunjukkan bahwa enzim ini bekerja optimal pada suhu $37-45{ }^{\circ} \mathrm{C}$ and $\mathrm{pH}$ 7. Enzim stabil ketika dilakukan penambahan $\mathrm{NaCl}$ sampai dengan $8 \%$ dan mulai berkurang ketika penambahan mencapai 16 dan $20 \%$. Penambahan ion logam $\mathrm{Mn}^{2+}, \mathrm{Mg}^{2+}$, and $\mathrm{Co}^{2+}$ dalam bentuk garam klorida mampu meningkatkan kinerja enzim sementara penambahan ion $\mathrm{Zn}^{2+}, \mathrm{Fe}^{3+}$, and $\mathrm{Ca}^{2+}$ mengurangi aktivitas enzim. Enzim ini diperkirakan memiliki berat molekul $42 \mathrm{kDa}$ dan $145 \mathrm{kDa}$
\end{abstract}

Kata kunci: L-glutaminase, bakteri laut, 16S rRNA, penapisan, karakterisasi 


\section{INTRODUCTION}

L-glutaminase (L-glutamine amidohydrolase, EC.3.5.1.2) is an enzyme that catalyzes the hydrolysis of L-glutamine into L-glutamic acid and ammonia. This enzyme is getting popular due to its important role and its applications in both pharmaceuticals and food industries (Nandakumara et al., 2003). L-glutaminase is proposed as an enzyme therapy for cancer, especially for acute lymphocytic leukemia, in combination or as an alternative to L-asparaginase (Siddalingeshwara et al., 2010; Abdallah et al., 2012). The mechanism of Lglutaminase as anticarcinogenic correlates with glutamine depletion due to inability of the lymphatic tumor cell to synthesize glutamine as the normal cells. Glutaminase is also taking an important role that controls the delicious taste of fermented foods such as soy sauce and in general food products by increasing the glutamic acid content therefore, this enzyme has attracted a great attention in food industries (Moriguchi et al., 1994; Alexandra et al., 2003).

Microbes i.e bacteria, fungi and yeast have been reported as potential L-glutaminase sources, and using that microbies as enzyme producers is more preferable due to their simple growth requirements, easy processing and handling as well as cheaper production cost. Reports showed that the majority of microbes producing L-glutaminase have been isolated from soil and aquatic (marine) environment (Nandakumara et al., 2003). Marine environment is expected as a unique L-glutaminase sources such as salt-tolerant and thermo-stable L- glutaminase which is needed by food industries (Desmond,1997; Prakash et al., 2009).

Screening of L-glutaminase from marine bacteria had been reported by Padma \& Singhal (2009), from marine Actinomycetes by Balagurunathan et al. (2010), and marine fungi by Sabu (1999). However, information on the L-glutaminase from Indonesia Sea is very rare. The objective of this present study was to isolate, screen and identify marine isolates producing L-glutaminase from Sangihe Talaud Sea, Indonesia. Characterization of the enzyme (crude enzyme) was performed from the best isolate producing the highest activity of L-glutaminase.

\section{MATERIALS AND METHODS}

\section{Qualitative Screening and Isolation of L-glutaminase Bacteria}

Samples (seawater) were collected by water samplers attached to CTD from $4 \mathrm{~m}$ until $1500 \mathrm{~m}$ depth of Sangihe-Talaud Sea in North Sulawesi, Indonesia during INDEX SATAL 2010 Cruise on R/V Baruna Jaya IV. The sample was kept cool until reaching laboratory. In the laboratory, $1 \mathrm{ml}$ of sample was taken from homogenized samples and initially added in to $20 \mathrm{ml}$ liquid modified Zobell's media containing $1 \mathrm{~g} / \mathrm{L}$ yeast extract and $5 \mathrm{~g} / \mathrm{L}$ peptone dissolved in artificial seawater (ASW). For qualitative screening, $1 \mathrm{ml}$ of enriched media containing the sample were grown in $100 \mathrm{ml}$ flasks containing $20 \mathrm{ml}$ media and put on water bath shaker at $100 \mathrm{rpm}$ maintained at $30{ }^{\circ} \mathrm{C}$ for 48 h. The medium contained $5.0 \mathrm{~g} / \mathrm{L}$ glucosa, $5.0 \mathrm{~g} / \mathrm{L}$ glutamine, $6.0 \mathrm{~g} / \mathrm{L} \mathrm{Na}{ }_{2} \mathrm{HPO}_{4} .2 \mathrm{H}_{2} \mathrm{O}, 3.0 \mathrm{~g} / \mathrm{L} \mathrm{KH}_{2} \mathrm{PO}_{4}$, $0.49 \mathrm{~g} / \mathrm{L} \mathrm{MgSO}, 0.05 \mathrm{~g} / \mathrm{L} \mathrm{NaCl}, 0.002 \mathrm{~g} / \mathrm{L} \mathrm{CaCl}_{2}$ and $0.06 \mathrm{ml}$ of $2.5 \% \mathrm{w} / \mathrm{v}$ ethanolic phenol red solution with pH adjusted to 7-8 (Padma \& Singhal, 2009). The sample that showed positive result was indicated by the color changes of media, and was further taken up for quantitative screening.

\section{Quantitative Screening for L-glutaminase}

$1 \mathrm{ml}$ of enriched media containing the positive samples from qualitative screening were grown by streaking in media containing $5.0 \mathrm{~g} / \mathrm{L}$ glucose, $5.0 \mathrm{~g} /$ $\mathrm{L}$ glutamine, $1,0 \mathrm{~g} / \mathrm{Lyeast}$ extract, $6.0 \mathrm{~g} / \mathrm{L} \mathrm{Na}_{2} \mathrm{HPO}_{4}$. $2 \mathrm{H}_{2} \mathrm{O}, 3.0 \mathrm{~g} / \mathrm{L} \mathrm{KH}_{2} \mathrm{PO}_{4}, 0.49 \mathrm{~g} / \mathrm{L} \mathrm{MgSO}{ }_{4}, 0.05 \mathrm{~g} / \mathrm{L}$ $\mathrm{NaCl}$, and $0.002 \mathrm{~g} / \mathrm{L} \mathrm{CaCl}_{2}$ with $\mathrm{pH}$ adjusted to $7-7.5$ for $48 \mathrm{~h}$ at $100 \mathrm{rpm}$ at $30^{\circ} \mathrm{C}$. The activity of extracellular L-glutaminase was estimated by spectrophotometer using Nessler reagent as described in analytical determination (Imada et al., 1973).

\section{S rRNA Sequencing Analysis of Selected Isolate}

DNA extraction was performed using commercial extraction of DNA. DNA amplification by PCR was performed using $F$ Primer (5'-CAGGCCT AACA CAGGCAAGTC-3') and R primer (5'-GGGCG GWG TGTACAAGGC-3'). Sequencing of amplification product of $16 \mathrm{~S}$ rRNA gene was conducted at 1st base life science in Singapore. The sequence obtained was initially analyzed at National Center for Biotechnology Information (NCBI) server (http://www.ncbi.nlm.nih.gov) using Basic Local Alignment Search Tool (Blast) and phylogenetic tree was constructed to identify the isolate (Marchesi et al., 1998).

\section{Growth Curve and Enzyme Production}

Growth curve of the isolate producing the enzyme was determined by inoculating 1 loopfull of bacteria in L-glutaminase media, composing of $5.0 \mathrm{~g} / \mathrm{L}$ glucosa, $1.0 \mathrm{~g} / \mathrm{L}$ yeast extract, $6.0 \mathrm{~g} / \mathrm{L} \mathrm{Na}_{2} \mathrm{HPO}_{4} .2 \mathrm{H}_{2} \mathrm{O}, 3.0 \mathrm{~g} / \mathrm{L}$ $\mathrm{KH}_{2} \mathrm{PO}_{4}, 0.49 \mathrm{~g} / \mathrm{L} \mathrm{MgSO}, 0.05 \mathrm{~g} / \mathrm{L} \mathrm{NaCl}, 0.002 \mathrm{~g} / \mathrm{L}$ $\mathrm{CaCl}_{2}$. Absorbancy at $600 \mathrm{~nm}$ was recorded every hour during the first $4 \mathrm{~h}$, followed by every $4 \mathrm{~h}$. To obtain enzyme production profile, measurement of enzyme 
activity was conducted following growth curve sampling. Preliminary study on the production of Lglutaminase was conducted by optimizing fermentation condition, i.e cultivation temperature of $25-35{ }^{\circ} \mathrm{C}$, shaker speed of 80 and $100 \mathrm{rpm}$, and inoculum volume of $5 \%$ and $10 \%$. The best result of the preliminary study was inoculum cultivation of $5 \%$, and $10 \%$ then used to produce L-glutaminase (Padma \& Singhal, 2009).

\section{Measurement of L-glutaminase Activity}

For estimation of L-glutaminase activity, a method developed by Imada et al. (1973) was used. The Lglutaminase produced in fermentation broth converts L-glutamine to L-glutamic acid and release ammonia. This ammonia then quantified by spectrophotometry using Nessler reagent. The reaction mixture contained $0.5 \mathrm{ml}$ of crude enzyme extract, $0.5 \mathrm{ml}$ of $0.04 \mathrm{M} \mathrm{L}$ glutamine, $0.5 \mathrm{ml}$ of $0.5 \mathrm{M}$ Tris-Cl buffer $\mathrm{pH} 8.4$, and $0.5 \mathrm{ml}$ distilled water. The reaction, at $37^{\circ} \mathrm{C}$ for 30 min, was terminated by adding $0.5 \mathrm{ml}$ of $1.5 \mathrm{M} \mathrm{TCA}$. Then, $0.2 \mathrm{ml}$ Nessler reagent was added to $0.1 \mathrm{ml}$ reaction mixture and made up to $4 \mathrm{ml}$ using distilled water. The absorbance of the mixture was measured at $450 \mathrm{~nm}$ after $20 \mathrm{~min}$ incubation at room temperature. One unit of L-glutaminase activity was defined as enzyme required for releasing $1.0 \mu \mathrm{mol}$ ammonia per min (Imada et al., 1973). The protein concentration was determined by the Bradford method using bovine serum albumin (BSA) as the standard.

\section{Characterization of Crude Extracellular L-glutaminase}

To determine the optimal temperature, the temperature ranges used to react the enzyme mixture was 20 to $60^{\circ} \mathrm{C}$. Optimal $\mathrm{pH}$ determination was carried out by using buffer solution ranging from 5 to 10 , i.e 6-8 using phosphate buffer, 8-9 using Tris- $\mathrm{HCl}$ buffer, and 9-10 using carbonate-bicarbonate buffer. Effect of salt on L-glutaminase activity was performed using addition of $0 \%$ to $20 \% \mathrm{NaCl}$. The effect of metal ions on the L-glutaminase activity on crude extracellular L-glutaminase were measured by similar L-glutaminase assays.

\section{SDS-PAGE}

Determination of the molecular weight of Lglutaminase, sodium dodecyl sulfate polyacrylamide gel electrophoresis (SDS-PAGE) was performed by using $12 \%$ polyacrylamide gel and stained with silver staining (Sabu, 1999).

\section{RESULTS AND DISCUSSION}

\section{Qualitative Screening and Isolation of L-glutaminase Producers}

Four samples of water collected from $4 \mathrm{~m}$ to 1000 $m$ depth gave positif result of L-glutaminase (Table 1 ) qualitatively, where as the 3 other samples collected from 1250-1500 m showed negative result. From the four samples, 13 isolates have been succesfully isolated and was taken into further screening quantitatively. The screening study showed that approximately 7 of the 13 isolates gave positive result of L-glutaminase. Among the 7 isolates, the isolate II.1 gave the highest L-glutaminase activity of 147.99 Unit/L or $62.32 \mathrm{Unit} / \mathrm{mg}$ of specific activity. This isolate which was taken from $400 \mathrm{~m}$ depth of Sangihe-Talaud Sea, was then selected for further study.

Table 1. Screening of L-glutaminase isolates from 4 different depths of Sangihe Talaud Sea

N.D : not detected 


\section{$16 S$ rRNA Sequencing Analysis of Selected Isolate}

The sequence homology studies showed the isolate II.1 had $96.0 \%$ similar to Pseudomonas aeruginosa strain CG-T8 (P. aeruginosa GU 339295.1). By comparing differences in the nucleic acid sequences of homologous genes from different organisms, a molecular phylogenetic tree was then constructed. The distance between the two sequences is an indicative of their relatedness to each other. Figure 2 showed the phylogenetic tree showing that our isolate had the same distance of relatedness with $P$. aeruginosa strain CG-T8 ( $P$. aeruginosa GU 339295.1) and Pseudomonas sp. HO 609591.1. Molecular identification based on 16S rDNA sequencing proposed the isolate as $P$. aeruginosa strain CT-G8 with $96 \%$ similarity. Genus Pseudomonas sp. has already known as a source of microbial glutaminase, along with other bacteria, fungi and yeast which are mostly isolated from soil, and it was produced extracellularly. Review on microbial Lglutaminase showed that Pseudomonas specifically $P$. aeruginosa, $P$. aurantiaca, $P$. aureofaciens, $P$. boreoplois, $P$. fluorescens, $P$. ovalis, $P$. schuylkilliensis and Pseudomonas sp. have secreted L-glutaminase (Nandakumar et al., 2003).

\section{Growth Curve of the Isolate II.1 and Production of the Enzyme}

Figure 3 showed growth curve of the isolate, showing that the isolate reach logaritmic phase after
$3 \mathrm{~h}$ cultivation up to $10 \mathrm{~h}$ cultivation, following stationary phase up to $21 \mathrm{~h}$. L-glutaminase enzyme was produced since $9 \mathrm{~h}$ cultivation and attained peak production at $22 \mathrm{~h}$ cultivation, which was in stationary phase of Isolate II.1 growth. From this data, this enzyme might be produced as secondary metabolites.

Preliminary study on optimizing the cultivation condition of L-glutaminase production was conducted by modified cultivation method of Padma et al. (2009). Figure $4(A, B, C, D)$ shows the optimization results demonstrating that the extracellular L-glutaminase from the II. 1 isolate was maximally produced when the isolate cultivated at $30^{\circ} \mathrm{C}$, in media having $\mathrm{pH} 6$, using volume inoculum of $5 \%$ and at shaking speed of $100 \mathrm{rpm}$. Based on the growth curve (Figure 3 ), the inoculum used was the 8-12 h old isolate having 0,65 0,75 Optical Density (OD) at $600 \mathrm{~nm}$ which was equal to $59 \times 10^{7}-69 \times 10^{7} \mathrm{CFU} / \mathrm{ml}$ of the inoculum used.

\section{Characteristics of L-glutaminase Enzyme}

The crude extracellular L-glutaminase produced by Pseudomonas aeruginosa strain CG-T8- II.1. performed optimally at $\mathrm{pH} 7,0$ and stable at $37-45^{\circ} \mathrm{C}$ Figure 5. A,B). The enzyme could tolerate $\mathrm{NaCl}$ concentration up to $16 \%$ and $20 \%$, and loosing the activity by $21 \%$ and $25.88 \%$, respectively. The effect of metal ions $\mathrm{Mg}^{2+}, \mathrm{Co}^{2+}$ and $\mathrm{Mn}^{2+}$ as $\mathrm{Cl}_{2}$ salt increased the activity, while addition of $\mathrm{Ca}^{2+}, \mathrm{Fe}^{3+}$, and $\mathrm{Zn}^{2+}$ reduced the activity (Figure 6. A,B).

Al Hammed \& Jassim (2011) reported that the activity of L-glutaminase from Serratia plymuthica was

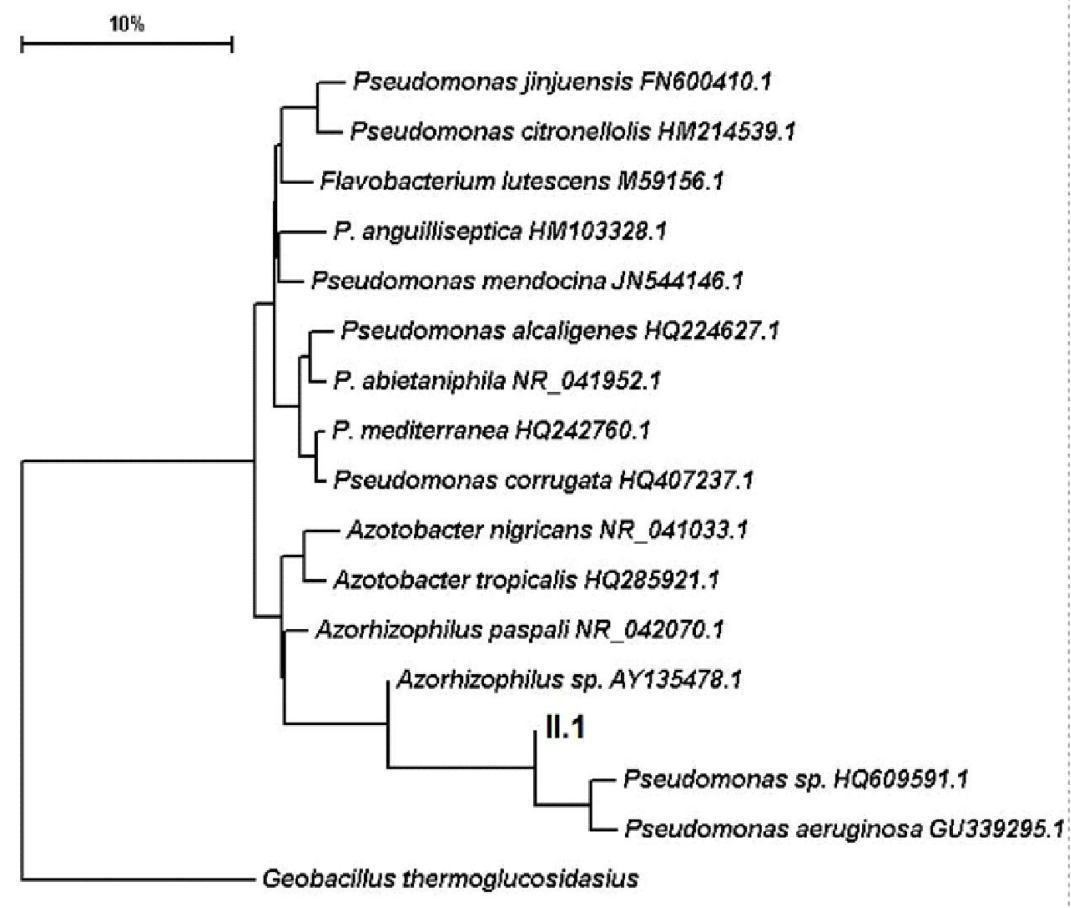

Figure 2. Phylogenetic tree of Isolate II.1 


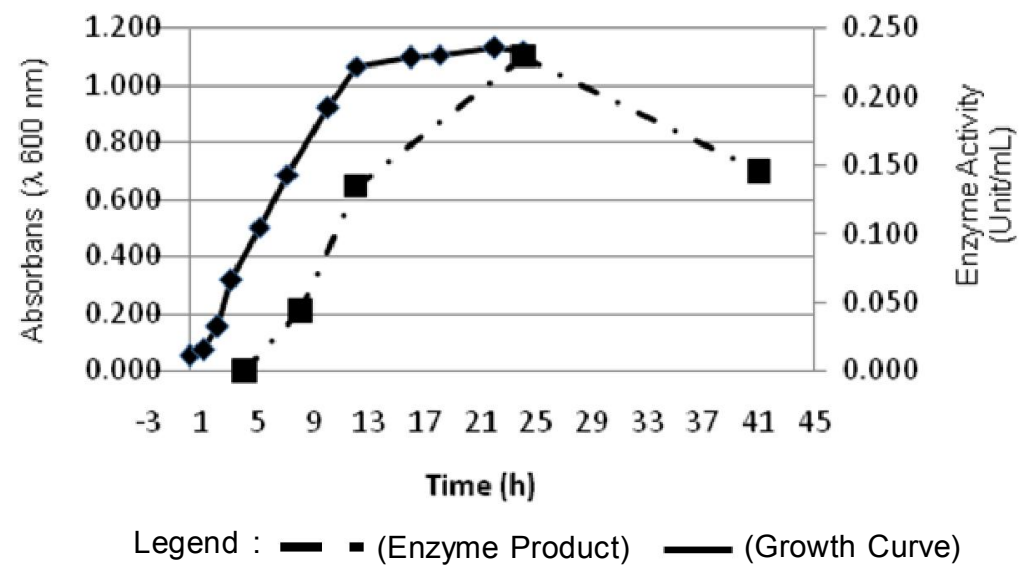

Figure 3. Growth curve of II.1 isolate and it's enzyme production

raised by addition of tetracycline and chloramphenicol with increasing specific activity of glutaminase up to $10.8 \mathrm{U} / \mathrm{mg}$ and $15.31 \mathrm{U} / \mathrm{mg}$ respectively, in comparison with the control of $3.1 \mathrm{U} / \mathrm{mg}$.

Salt tolerance L-glutaminase was important for its application, especially for food industry needs. It was reported that marine isolates $M$. luteus K-3 and $B$. subtilis were shown to be highly salt-tolerant up to 16 and $25 \%$ of $\mathrm{NaCl}$, respectively. Isolate II. 1 produced
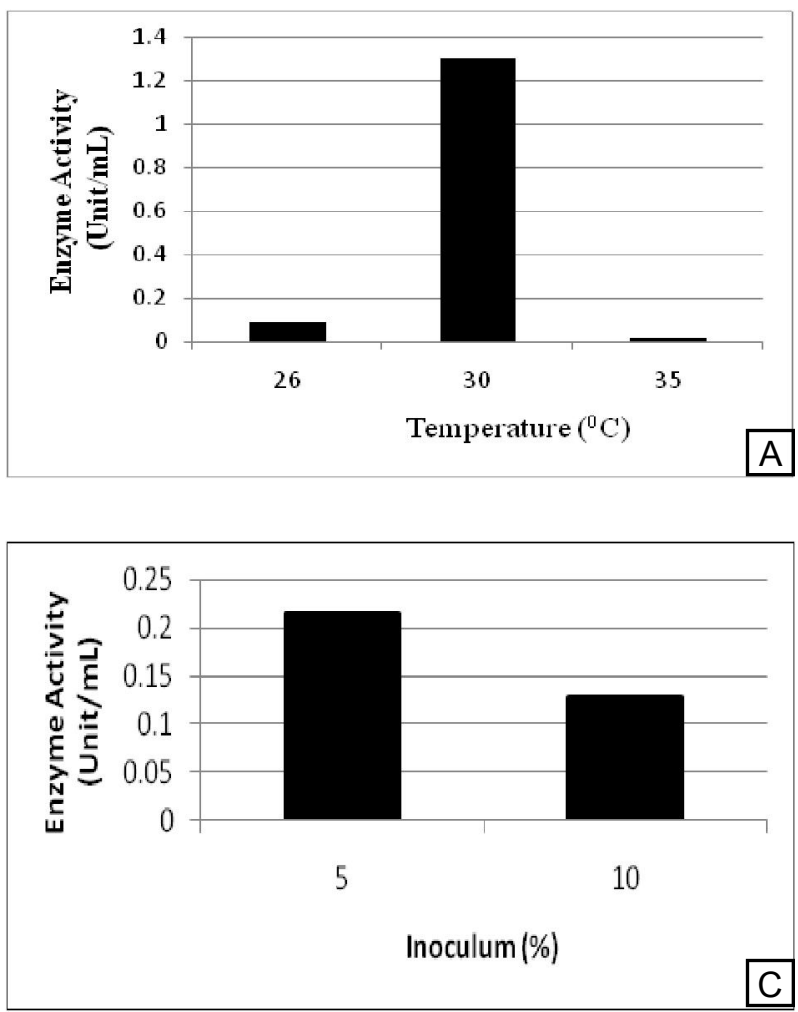

quite stable L-glutaminase. However, the relative activity of the enzyme decreased by $21 \%$ when added with $16 \% \mathrm{NaCl}$ solution.

Result of SDS-PAGE of the enzyme showed the occurence of two (2) protein bands of $42 \mathrm{kDa}$ and 145 $\mathrm{kDa}$ in all samples, i.e crude enzyme, ultrafiltration fraction and amonium sulphate fraction. It was assumed that the bands represent the sub unit and native enzyme from glutaminase class $\mathrm{A}$. As mentioned
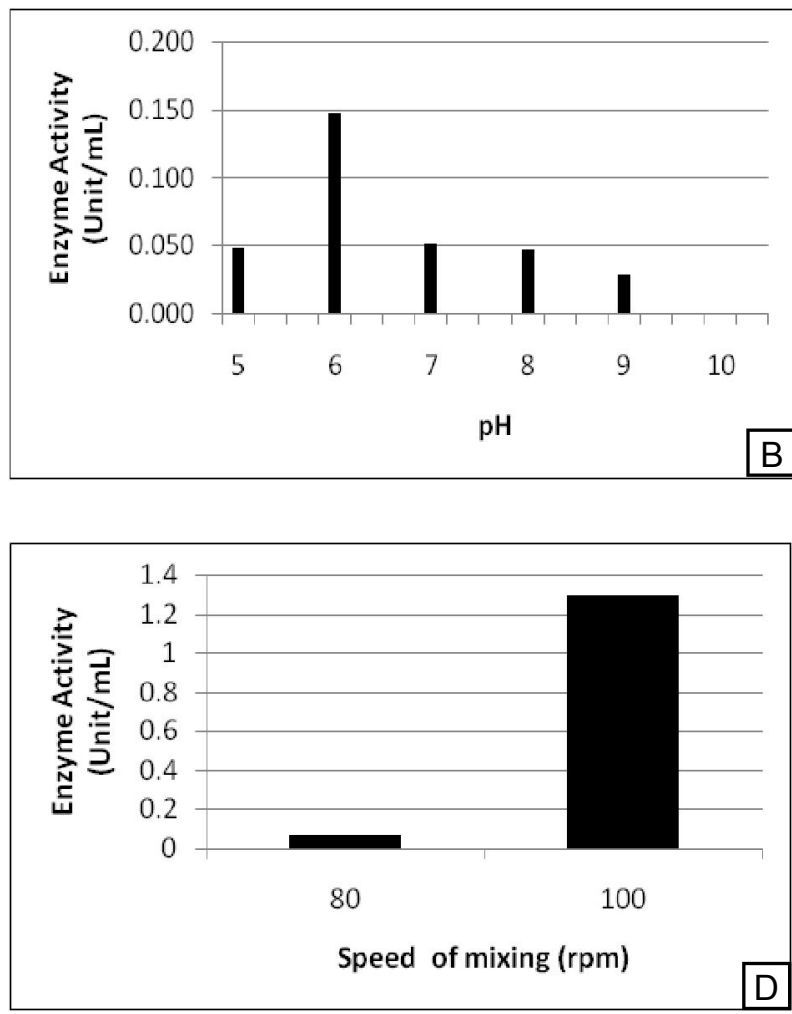

Figure 4. Production of the enzyme at different treatment: $(A)$ incubation temperature; (B) pH media; (C) 2 (two) different concentration of inoculum; (D) mixing speed. 


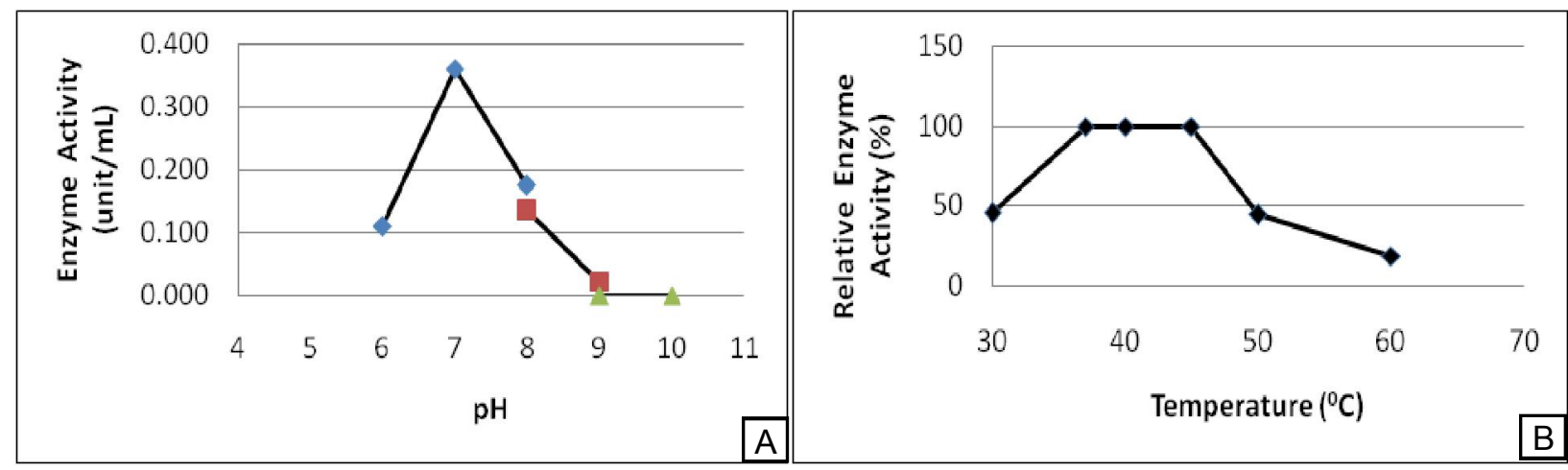

Figure 5. (A) $\mathrm{pH}$ and (B) Optimum temperature of L-glutaminase produced by Pseudomonas aeruginosa strain CG-T8- II.1.
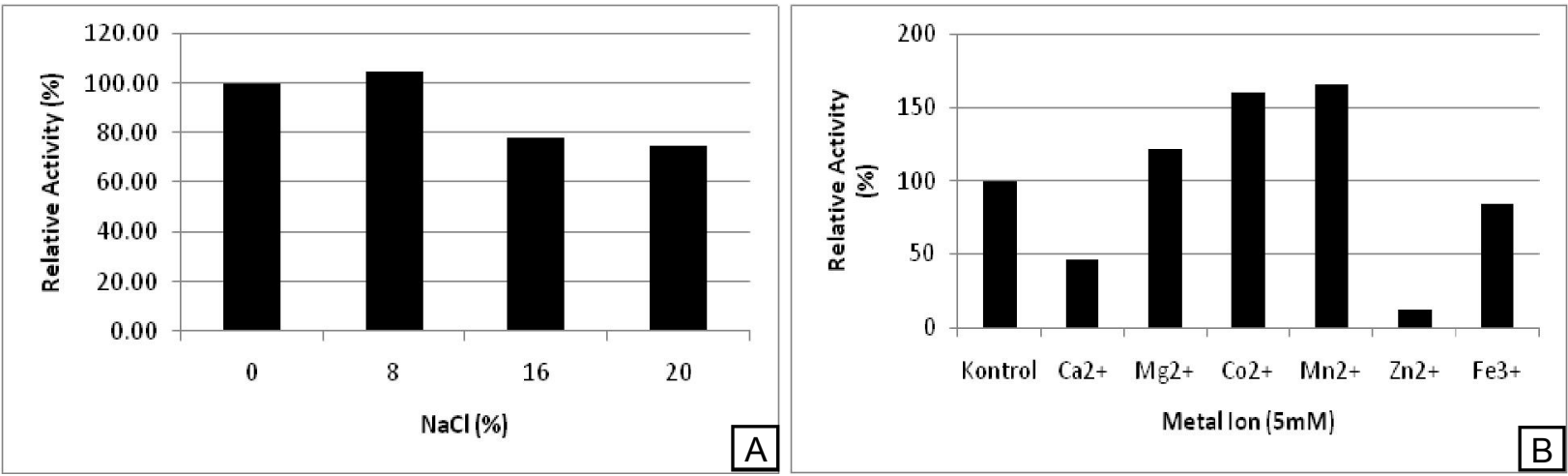

Figure 6. (A) Effect of $\mathrm{NaCl}$ and (B) metal ion as chloride salt on the enzyme's activity.

in the literature glutaminase class A having molecular weight around $35 \mathrm{kDa}$ and $137 \mathrm{kDa}$ (Nandakumara et al., 2003).

\section{CONCLUSION}

L-glutaminase producing marine bacteria was isolated from Sangihe-Talaud Sea, North SulawesiIndonesia from the depth $400 \mathrm{~m}$ with the activity of $147.99 \mathrm{Unit} / \mathrm{L}$ or $62.32 \mathrm{Unit} / \mathrm{mg}$. Identification using $16 \mathrm{~S}$ rRNA sequencing revealed the isolate has $96 \%$ similarity to Pseudomonas aerginosa strain CT-G8. L-glutaminase has been produced maximally in fermentation condition of $30^{\circ} \mathrm{C}, 100 \mathrm{rpm}, \mathrm{pH}$ of media 6,0 , and with starter inoculum of $5 \%$. The crude enzyme can perform optimally at $37-45^{\circ} \mathrm{C}, \mathrm{pH} 7.0$ and retain $>50 \%$ relative activity when added with $\mathrm{NaCl}$ up to $20 \%$. Addition of metal ions $\mathrm{Mg}^{2+}, \mathrm{Co}^{2+}$, and $\mathrm{Mn}^{2+}$ in the form of $\mathrm{Cl}^{2+}$ increased the enzyme activity, while addition of other metal ions $\left(\mathrm{Ca}^{2+}, \mathrm{Fe}^{3+}\right.$, and $\left.\mathrm{Zn}^{2+}\right)$ decreased the enzyme activity. Result of SDS-PAGE revealed that the L-glutaminase might approximately had molecular mass of 42 and $145 \mathrm{kDa}$.

\section{REFERENCES}

Abdallah, N.A., Amer S.K., and Habeeb, M.K. 2012. Screening of L-Glutaminase Produced By Actinomycetes Isolated From Different Soils In Egypt. International Journal of ChemTech Research. 4(4): 1451-1460.

Alexandra, W.Z., Christiane, G. D., Affolter, M. 2003. Functional Characterization of a Salt-and Thermotolerant Glutaminase from Lactobacillus rhamnosus. Enzyme and Microbial Technology. 32: 862-867.

Al Hammed, A.M.A. and Jassim, I.M. 2011. Effect of the antibiotics on Glutaminase purified from Serratia plymuthica isolated from diyala rive. Diyala Agric. Sci. Journal. 3(1): 22-33.

Balagurunathan, R., Radhakrisman, M., and Somasundaram, S.T. 2010. L-glutaminase Producing Actinomycetes from Marine SedimentsSelective Isolation, Semi Quantitative Assay and Characterization of Potential Strain. Australian Journal of Basic and Applied Sciences. 4(5): 698-705.

David, A. 2004. Significance of Bacterial Identification by Molecular Biology Methods. Endodontic topics. 9:514. 
David, R.W. and Craig, B.T. 2010. Glutamine addiction: a new therapeutic target in cancer. USA Trends in Biochemical Sciences. 35: 427-433.

Desmond, K. O'toole. 1997. The Role of Microorganisms in Soy Sauce Production. Advances in Applied Microbiology. 45: 87-152.

Imada, A.I., Nakahama, K., and Isono, M. 1973. Asparaginase and Glutaminase Activities of Microorganism. Journal of General Microbiology. 76: 8599

Marchesi, J.R., Sato, T., Weigtman, A.J., Martin, T.A., Fry, J.C., Hiom, S.J., Dymock, D., and Wades, W.G. 1998. Design and Evaluation of Useful Bacterium-Specific PCR Primers That Amplify Genes Coding for Bacterial 16S rRNA. Appl. Environ. Microbiol. 64: 795-799.

Nandakumara, R., Yoshimune, K., Wakayama, M., and Moriguchi, M. 2003. Review Microbial glutaminase: biochemistry, molecular approaches and applications in the food industry. Journal of Molecular Catalysis B: Enzymatic. 23: 87-100.

Origuchi, M., Sakai, K., Tateyama, R., Furuta, Y., and Wakayama, M. 1994. Isolation and Characterization of Salt-Tolerant Glutaminases from Marine
Micrococcus luteus K-3. Journal of Fermentation and Bioengineering. 77(6): 621-625

Padma, V., lyer, and Rekha, S.S. 2009. Screening and Selection of Marine Isolate for L-Glutaminase Production and Media Optimization Using Response Surface Methodology. Appl. Biochem. Biotechnol. 159: 233-250.

Prakash, P.J.E., Poorani, P., Anantharaman, and Balasubramaniam, T. 2009. L-glutaminase Production and the Growth of Marine Bacteria. Research Journal of Microbiol. 4: 168-172.

Sathish, T. and Prakasham, R. S. 2010. Isolation an Identification of L-glutaminase an Antileukemic Enzyme Producing Micro-organism from Godavari River Bank Soils in Andhra Pradesh. International Research Journal of Pharmacy. (1): 367-373.

Sabu, A. 1999. L-glutaminase Production by Marine Fungi, Thesis. Department of Biotechnology COCHIN University of Science and technology. $682022: 168$.

Siddalingeshware, K.G., Dhatri, D.N., Pramada, T., Vishwanata, T., Sudipta, K.M., and Mohsin, S.M. 2010. Rapid Screening and Confirmation of L-Glutaminase producing novel Aspergillus wentii. International Journal of Chem. Tech. Research. 2(2): 830-833. 